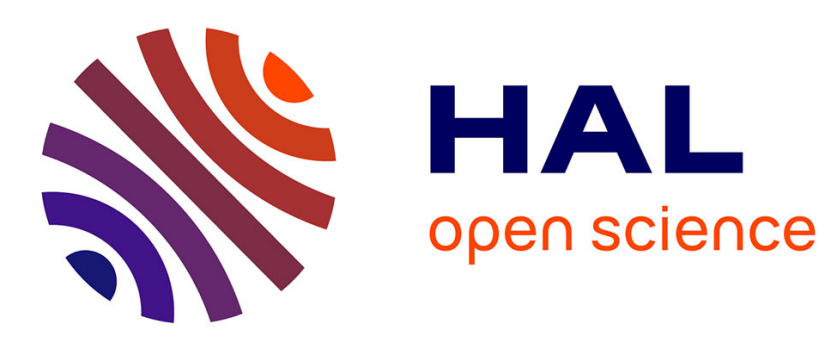

\title{
From the Mother's Non-Desire to the "Incestual" Relationship between Father and Daughter
}

\author{
Mireille Bertholet-Guittonneau
}

\section{To cite this version:}

Mireille Bertholet-Guittonneau. From the Mother's Non-Desire to the "Incestual" Relationship between Father and Daughter. Recherches en psychanalyse, 2012, Corps, identité et traumatisme / Body, Identity and Trauma, 2 (14), pp.155-164. 10.3917/rep.014.0155a . hal-01509928

\section{HAL Id: hal-01509928 \\ https://hal.science/hal-01509928}

Submitted on 18 Apr 2017

HAL is a multi-disciplinary open access archive for the deposit and dissemination of scientific research documents, whether they are published or not. The documents may come from teaching and research institutions in France or abroad, or from public or private research centers.
L'archive ouverte pluridisciplinaire HAL, est destinée au dépôt et à la diffusion de documents scientifiques de niveau recherche, publiés ou non, émanant des établissements d'enseignement et de recherche français ou étrangers, des laboratoires publics ou privés. 


\title{
FROM THE MOTHER'S NON-DESIRE TO THE "INCESTUAL" RELATIONSHIP BETWEEN FATHER AND DAUGHTER
}

\section{Mireille Guittonneau}

\author{
Association Recherches en psychanalyse | Recherches en psychanalyse »
}

2012/2 $\mathrm{n}^{\circ} 14 \mid$ pages 155a à 164a

ISSN 1767-5448

Article disponible en ligne à l'adresse :

http://www.cairn.info/revue-recherches-en-psychanalyse-2012-2-page-155a.htm

\section{Pour citer cet article :}

Mireille Guittonneau, "From the Mother's Non-Desire to the "Incestual" Relationship between Father and Daughter », Recherches en psychanalyse 2012/2 $\left(\mathrm{n}^{\circ} 14\right)$, p. 155a-164a.

DOI 10.3917/rep.014.0155a

Distribution électronique Cairn.info pour Association Recherches en psychanalyse.

(C) Association Recherches en psychanalyse. Tous droits réservés pour tous pays.

La reproduction ou représentation de cet article, notamment par photocopie, n'est autorisée que dans les limites des conditions générales d'utilisation du site ou, le cas échéant, des conditions générales de la licence souscrite par votre établissement. Toute autre reproduction ou représentation, en tout ou partie, sous quelque forme et de quelque manière que ce soit, est interdite sauf accord préalable et écrit de l'éditeur, en dehors des cas prévus par la législation en vigueur en France. Il est précisé que son stockage dans une base de données est également interdit. 


\section{Recherches en Psychanalyse - Research in Psychoanalysis}

\section{From the Mother's Non-Desire to the "Incestual" Relationship between Father and Daughter}

Du non désir maternel aux relations incestuelles entre père et fille

[Online] Dec. 28, 2012

Mireille Guittonneau

\section{Abstract:}

The organization of some families can only be understood when we link together two seemingly separate stages: an "incestual" relationship with the father, supported by the mother's non-desire for their daughter. This is why some girls accept such a relationship with their father: they try to exist in their mother's eyes instead of being constantly erased from them. But this relationship, which is structured by their mother's non-desire and often masked by cultural tradition, is fraught with consequences on their ability to integrate temporality: we observe a "dwarfed" temporality that can only be unfolded in the transference, in analytic work.

\section{Résumé:}

Certains fonctionnements familiaux ne s'éclairent qu'à partir du moment où peuvent être mises en lien deux scènes apparemment séparées : une relation incestuelle avec le père soutenue par le non désir maternel à l'égard de leur fille. Car c'est bien là ce qui conduit certaines filles à se soumettre à une telle relation avec leur père : tenter ainsi d'exister dans le regard maternel au lieu d'en être constamment effacées. Mais cette relation, structurée par un non désir maternel souvent masqué par des traditions culturelles, est lourde de conséquences sur la capacité de ces jeunes filles à s'inscrire dans le temps. On constate ainsi la formation d'une "temporalité écrasée ", dont le déploiement passe par la relation transférentielle inhérente au travail analytique.

Keywords: incestual relationship, maternal non-desire, effacement of the subject and its cultural forms, dwarfed temporality

Mots-clefs: relation incestuelle père-fille, non désir maternel, effacement du sujet et ses formes culturelles, temporalité écrasée

\section{Plan:}

On an Incapacity to Think through Bonds

Cultural Forms of the Effacement of the Other

A Temporal (Mis)shaping: A Bi-dimensional "Dwarfed" Time

When the Fright of a Word, Greeted in the Transference, Opens onto the Creation of Bonds that Hitherto Were Unthinkable

An Errant Primal Scene at the Heart of the Process

The Creation of Links, the Unfurling of Time

\section{Conclusion}


Described by P. C. Recamier as "a climate in which the winds of incest blow without there actually being any incest" ${ }^{1}$, taking form in acts that go beyond the single register of the gential, the "incestual" is founded, according to him, upon an errant narcissistic seduction. Here, there is no symmetry in the early exchanges, but rather a relationship that is weighted entirely in the favor of the adult.

Having become an ascendent hold, the narcissistic seduction inscribes the budding relationship and the relationship under the aegis of the "twain". Nothing and no one can come between them, not now, not ever. Indeed, this relationship of an ascendent hold heralds, whether explicitly or not, that they are sufficient unto one another, that together they fear nothing and that any separation would entail the death of he or she that might decree this pseudo law.

Thus, as is underscored by the fantasy that organizes the incestual relationships, the scene is acted out by two players. However, in this familial configuration, what about the third term, the father or the mother? Is it simply ousted, in the deeds or speech, a mere witness or immobile and silent accomplice?

We shall hypothesize that in certain incestual families, two plays are being acted out simultaneously on the same stage: an incestual father/daughter relationship and a mother / daughter relationship that is stamped with the violence of a maternal non-desire that is at first concealed, while still giving rise to crazy messages. But this non-desire breaks out as soon as the child, now an adolescent, dares to take a stand and stake a claim to desires and points of disagreement. The following sentence had been uttered by their mothers: "It would have been better if you had flown out with the blood of my period!", which was then offered up to my listening ear by several of my female patients, at different times and places, leading me to examine the father/daughter incestual relationship in light of the existing relationship between mother and daughter. Indeed, this sentence suddenly seemed to resemble umpteen scattered and paradoxical messages with which these women had been faced from the start and it sheds light on the fantasy that lies at the heart of these two relationships that previously stood apart. So, is it not this effect of gathering together and organizing these implicit messages that produces an effect of meaning by bringing home the non-desire of their mother towards them? And whilst the expression of this non-desire delivers them up at first to an identification that cannot be sustained, we shall postulate that, paradoxically, it is also what allows them thereafter to extract themselves from the incestual relationship to which they were hitherto submitted. On the condition, however, that this speech is taken on board by a listening ear that, by sketching out new bonds, favors the recomposition of positions and identifications.

For us, it is therefore a matter of exploring starting off from the history of these young women - some of the processes that organize the mother/daughter relationship in familial configurations that are marked by an incestual relationship between father and daughter.

After having brought out the ravages wreaked on the bonds in such functioning, we shall be seeing, in particular, that some cultural representations linked to the fact of being a girl and of giving life to a girl, can reinforce odd intra psychical and familial functioning, thus giving them greater visibility. Thus, we shall be showing how cultural demands sometimes mask over a de-subjectifying trend that effaces these girls who are crushed, among other factors, by their role as eldest daughter. We shall then study some of the consequences that such a movement can have on their capacity to inscribe themselves in a structuring temporality, and in particular, the shaping of a bi-dimensional dwarfed time.

Lastly, we shall also be underlining the importance of hearing the multiple effects that are sometimes created by condemnations that cause dread, some of which are at the very least unexpected, opening up the path to "subjective becomings". 2 


\section{On an Incapacity to Think through Bonds}

In such familial configurations, it is first and foremost the capacity to think through bonds that seems to be affected and stamped with a form of prohibition. Thus, the speech of these young women made two different relations to the twain appear without the slightest shadow of a triangulation ever being hinted at. Indeed, these two relationships, on one side to the father, on the other side to the mother, seemed to be following separate paths. Two scenes unfurled, side by side, but apparently devoid of any link between them. Even so! A father presented as such a tender man, so different from a mother who is not in the least bit understanding and who causes fury, rage and despair in these young women in their borderline functioning. Indeed, they seemed to be struggling in vain, striving to free themselves from the mesh of an invisible net in an incessant fight against an enemy with enigmatic motives. Despite all their efforts, they were nevertheless incapable of making sense of what was being played out between their mothers and themselves. By turns, and simultaneously, confronted with a distancing, with silence and then the chaos of a relationship that was not managing to form, they seemed to cling $^{3}$ to their mothers; a desparate attempt to make a subjectifying relation exist, but without success. For, whatever their mothers' contradictory and inexhaustible demands might be, regardless of the violence of their looks and words, none of these young women were able to take flight. They stayed put, and put up ${ }^{4}$ with their mothers. Moreover, the fury and the despair that often gripped them were cancelled out by the image of an "exemplary mother" that family and friends would keep alive. Indeed, these people from the subject's ambit showed admiration for women who had "been through so many ordeals and fulfilled their role of mother so well", whenever a public audience was present. Consequently, not only did the wording of each and every complaint become inconceivable, but more serious still, the very legitimacy of their inner pain found itself called into question. Beside this, the incestual relationship with the father seemed to be free of discord, a haven of peace that there was no cause to examine.

\section{Cultural Forms of the Effacement of the other}

Zaïna, a young woman of Pakistani origin, seemed to be lost. Even though she was married and the mother of a young boy, she seemed to be incapable of leaving behind the family home to which she returned each and every day. Through the thread of her speech, her impossible conquest took shape: to be recognized by her mother in her singular desires and in her very existence. Indeed, her mother seemed not to see her, so much did Zaïna seem to be concentrated on the image that she had to present to the eyes of her social group: the eldest daughter. To respect the tradition, which defines the roles of all its participants, seemed to be the essential mission that fell to Zaïna. Like Aïssatou and Kumba, she was there to aid her mother, to carry out in her place the various tasks of everyday life. Thus, further to taking care of the upkeep of the house and the cooking, Zaïna looked after the younger ones. But the more she strove to fulfill this role, the more she disappeared from her mother's gaze. Considered as her mother's double, she found herself annulled in as much as the tasks she carried out went "without saying", and were "normal" for an eldest daughter. Thus, Zaïna's life, like the lives of Aïssatou and Kumba, seemed to be organized around one fundamental question: how is one to manage to exist in the eyes and the desire of one's mother? And this quest had led them into dead ends, including that of submitting to incestual relations with their father.

So, their everyday life had always been marked by manifold and contradictory demands in the midst of which they could not find their way. So it was that Zaïna explained to me that, although as the elder daughter she should be fully 
present to help her mother, even to replace her, her sexual identity had always designated her in her link with her future departure. ${ }^{5}$ So as to allow me to grasp more accurately the nuances of this Urdu expression, she used the following image: "a girl is said to be a lent object, left as a provisional deposit and soon to be retrieved by its owner". Thus, some young Pakistani girls are from the very outset marked by a gaze that anticipates their departure and seems to say, "she is a girl, and therefore she is not my child", denying them the possibility of inscribing themselves in a present tense affiliation. For, although there are numerous mothers who manage to free themselves of such a prescription so as to live in the present tense of a budding encounter and form with their daughter a "good enough" ${ }^{6}$ relationship, others, grappling with a painful personal history, can only deliver their daughter up to the violence of a gaze inhabited by her present and future absence. So, we can understand here that this cultural designation gives a very particular visibility to the destructive potential of certain maternal gazes which are very often haunted by former traumatic mishaps and ruptures, but are not limited to a specific cultural background. Indeed, neither Kumba nor Aïssatou ${ }^{7}$ had experienced a nomination of this sort. But the crux of it was played out, for them too, under a desubjectifying maternal gaze, forbidding them to be girls and more generally forbidding them to be alive.

Indeed, it is the non-desire to give life to a girl that thus impresses itself and imparts its coloration to the budding relationship. A nondesire that, sometimes, can only be transformed into a desire for the new born's death. This was the case for Zaïna, whose mother seemed to be gripped by a particular pattern in her appellation of the young girls in order to express this desire for death. More generally speaking, we notice therefore than in effacing their young daughters from their gaze, by reducing them, for example, to their social, cultural and familial status, some mothers carry through, in a symbolic form, the desire for death that dwells within them, transforming their daughter into a being who, "already, is no longer there".

\section{A Temporal (Mis)shaping: A Bi-dimensional "Dwarfed" Time}

We are going to see that an anticipation of this kind, carried here by a social prescription, simply puts a shine upon the odd relation to time that is sometimes established when the mother's gaze abolishes all living presence. Indeed, the anticipation of their absence to come, thereby put in the service of the death drives, seems to shrink down the time that is lived out by these young girls, then by these women, in two of its dimensions: the past and the future. Now, this bi-dimensional time $e^{8}$ cannot contribute to the construction of a psychical base from which a psychical space equipped with a trustworthy envelope could emerge. Indeed, if one considers more precisely the future of this dwarfed temporality, one notices that it is not a matter of some living future, of a locus of projections, like the one that participates in day dreams and literary creation when a present tense desire appears fulfilled in the future on the model of the past. ${ }^{9}$ For here, both past and future present only one and the same face: that of their effacement, which is repeated afresh with each gaze. This future is not therefore the locus of an identifactory project ${ }^{10}$ either, which by essence is always in movement. How indeed can one form for onself a representation of one's future existence when live and death are confused, when in order to live one has to die beforehand? Consequently, the veil is drawn back on a future assassin, borne by Thanatos, who annuls the present tense of a feminine existence in order to turn it into a figure of the past. However, because it has never really been fleshed out in a present that has been lived and shared, this figure of the past does not belong to the register of memories but finds itself reduced to a shallow, shadowy phantom. Thus, having been effaced from the present since the very start, these young women have never been 
able to exist in their singularity and have found themselves to be frozen in their simple status as the "eldest daughter", which in these conditions is particularly de-subjectifying. Bereft of the presence of a wider circle of individuals around them who could "see and hear", might not these young women be in a similar situation to the one described by $C$. Lévi Strauss when a group, having cursed an individual, stops seeing him, hearing him, considering him to be already dead? ${ }^{11}$ Now, C. Lévi Strauss underlined the impossibility for anyone of ever resisting, of ever outliving, such treatment for very long; physical death would soon fulfill the destructive aim of the curse. In the story of these young women, other gazes and other words have allowed them to grow up and to build themselves up at least to a minimal degree beyond the shadow of themselves that the mother's gaze reflected back at them. And yet, these other gazes, of a grandmother or an aunt, had not succeeded in detaching them from their quest: to exist in the mother's gaze. On the contrary, their entire conduct seemed to be turned towards the mother with her destructive gaze; as though they had first to find a place in this original gaze so as then the gaze of others might take on its full value. Indeed, right where the mother's gaze had fallen short, right where it was unable to constitute a mirror ${ }^{12}$, a major narcissistic fault opened up that altered the relationship to the self and the relation to others.

It is then the transference that can aid patients such as these to gain a hold over an existence in the present, in a subjectifying relationship, loosening the stranglehold of certain identifications that cannot be sustained while bringing out the bonds that hitherto had not been thought through. So it was that, as the sessions wore on, each of the young women managed, bit by bit, to restore legitimacy to their suffering, to their impression of not having had a mother. Their suicide attempts during adolescence were progressively inscribed as a desperate will to bring forth from their mothers the expression of a desire for life, much more than as a manifestation of Thanatos. However, their mothers' non-desire in their regard could only emerge through tiny hints, so dangerous was its full acknowledgement, annulling all hope and any possibility of taking up a place in the maternal gaze and of going on living. Now, neither of them has given up, even if this hope was condemning them to maintain themselves in a functioning that was governed by paradoxes. For, despite their efforts, this hope led them inexorably to the maternal equation which stipulated that their disappearance was something that was desired.

When the Fright of a Word, Greeted in the Transference, Opens onto the Creation of Bonds that Hitherto Were Unthinkable

In parallel to this, in the midst of the storms that were stirring up the mother/daughter relationship, their appeared sporadically and momentarily the other relation whose incestual relation was gradually revealed: one father takes his daughter as his confidante, sharing with her the difficulties he experiences in the parental couple, another father lies down beside his daughter wordlessly and without a gesture. Secrets that are not really secrets are exchanged between father and daughter, and so forth. Thus, what had previously been the obvious fact of a soothing relationship progressively gave way to doubt. Each of the young women wondered exactly what the true nature of this relationship was. However, these two relationships, with the father and with the mother, continued to co-exist without any link between them being accessible to thought. Moreover, it was paradoxically the upsurge of a violent sentence - "it would have been better if you had flow out with the blood of my period" that allowed a bond to appear, once the first effect of astonishment had passed. For initially it was the violence that made its impression, through the coming to light of the mother's non-desire. How indeed are they to face up to the "formless"13 image of themselves that is reflected back to them by the discourse the 
mother holds? A formlessness that here we may note has been brought strongly to the fore by words from the mother that are full of images, as African or Indian languages can be; the appeal to the sensory dimension accentuates the force of the image and the effect of astonishment it produces. S. Le Poulichet, in her work on formlessness, has shown the function of the "identification of anxiety" ${ }^{14}$ that is present in such words to the extent that they "assign to the body a hotbed of disintegration or decomposition". ${ }^{15}$ Thus, "terrors of formlessness" ${ }^{16}$ are sometimes constituted which deeply affect the psychical construction by producing an "identificatory wavering". ${ }^{17}$ But over and above the condemnation contained in the mother's words, S. Le Poulichet has shown the major role that is played by the mother's gaze; a gaze whose points of failure we have seen in the stories of Zaïna, Aïssatou and Kumba. Thus, with regard to "terrors of formlessness" and the "identification of anxiety", she writes that they "are particularly developed when the face has remained unconvered, in the anxiety of being fundamentally watched from no fixed point and by no one, this face not having been sufficiently grasped in a form nor covered over with the insignia of the recognition of the primordial Other. The identification of anxiety thereafter provokes a precipitation, in a space without edges, in a real with no base, in which a verdict seems to be uttered: "thou art formless", which comes in echo of a condemnation uttered to a parental other." ${ }^{\prime 18}$ Thus, at the very moment at which the maternal mirror had finally become clear, these young women had discovered in it an intolerable image of themselves. More than a reflection from elsewhere, these words had appeared as a retrospective slaying. For it is only by remaining formless, by flowing out in the menstrual blood, that they could have satisfied the mother's desire. And for each of them this identification gave rise to fright. How indeed can one envisage onself in an ideal image of the self when stemming from a disappearance, a formless flow repeated each month, first in their mother's body, then in their own body?
However, as soon as the fright of this identification was able to be deposited in the sessions, a recomposition of their childhood history came into effect. Considered through the prism of the maternal non-desire, their mothers' contradictory requirements, which were sometimes quite insane, finally took on meaning. Thus Aïssatou was able to read some of her mother's doings in a new light, including her refusal to get her hygienic sanitary protection when puberty set in. Throughout her entire adolescence, she had therefore had to manage with scraps of tissue paper taken from here and there.

\section{An Errant Primal Scene at the Heart of the Process}

Through this phase of the therapeutic work, what until then they had been fleeing from impressed itself upon them. But far from bringing about the dreaded morbid design, becoming conscious of this non-desire appeared as a liberation, the possibility of extracting themselves from a lure that until then they had maintained. In this sense, the mother's words represented the death of the mother / daughter relationship that was desired in vain, thereby opening the door to the grieving process. Suddenly, they no longer had to endure anything and everything in the futile and mad hope of satisfying this maternal desire, of existing in her desire and her gaze. For, until then, they had been fastened to the fantasy that, as P. Aulagnier had it, organizes the primary mode of representation, making every experience "the realization of the desire of the Other". ${ }^{19}$ This author underlines that displeasure can thus become pleasure for the one who feels it as soon as it seems to conform to the expectations of the Other. And it is precisely here that we meet what led these young women to submit to an incestual relationship with the father: again, as always, it was a matter of satisfying the mother's desire and of existing in her gaze. Indeed, faced with the conjugal disaccord, against the background 
of an arranged marriage for each of the three mothers, each of the young girls thought she was answering the mother's desire by bowing to the ambiguity of an incestual relationship with their father, thereby offering themselves in sacrifice, in place of their mothers. In this way, they had been hoping to put a stop to the insidious violence, the words and deeds, that typified the parental couple. Whether it remained a mere threat, lurking in the shadows, or broke out in a visible form, this violence gave great complexity to the possibility the girls had of forging for themselves a representation of their origin as a consequence of parental desire. Thus, for want of being able to think through their parents' desire - in a primal scene that would have a structuring function, truly constituting a point of origin - they had displaced it. Instead of being the desire for their entry into the world, it had become the desire for them to sustain this strange relationship with their fathers. In this way, they had therefore constructed an unconscious scenario in which there really did exist at the heart of the parental couple a shared desire that concerned them. But here again, they had been sidetracked, so enigmatic and impossible to satisfy did this parental desire remain, in spite of their efforts. Besides, far from giving them substance, the incestual relationship cancelled out all their singularity, and all their subjectivity along with it. In the relationship with the father, just as in the relationship with their mothers, they found themselves reduced to mere shadows of themselves.

Now, by imposing the existence of a non-desire, the mother's words seemed to have made such fantasies null and void. Indeed, the identifycation of these young women, such as it was unveiled by the discourse the mother held, was not limited only to the formless image of the flowing blood, of a life that ought never to have taken shape, but also took in the notion of impurity. And this implicit reference to impurity was received by them as a sign of disapproval, a condemnation of the ambiguous relationship they maintained with their fathers. Thereafter, it was no longer possible to think that this relationship was enabling them to be recognized by their mothers, to satisfy, in this fashion, their desires. Guilty for being alive, they also became guilty for the relationship that had been established between them and their fathers. Thus, the blood that might once have flown led these young women to the blood that each month flowed from them, finishing off in a certain fashion the identification stated by the mother. For Aïssatou, the bond was twofold: hadn't her mother interpreted the early onset of her menstrual cycle as the consequence of her forbidden sexual desires? Thus, Aïssatou had built herself upon a delusional theory, uttered as the truth by a mother who declared she knew everything her children thought, their every secret act and desire.

The Creation of Links, the Unfurling of Time

A process of grieving was then able to get underway, allowing them to put to work the two relationships whose link had finally been brought to light. And it was precisely this highlighting of a fundamental link between these two relationships that allowed the said relationships to be untied. Now extracted from a mortifying assault, the young women certainly remained in the grief of renunciation, but for the first time protective measures could be implemented. Little by little, each of the young women authorized themselves to take some distance from her mother, to the point of almost ending any relationship, so as to be submitted no longer to gestures and words whose destructiveness seemed to amplify the more their will to affirm their desires and singularity emerged. No longer caught up in a future that was constantly annulling them, all three of them were ultimately able to invest in the present tense of their lives, whether this took the form of a relationship with their husbands, with their children, or their home environment: whereas Zaïna seemed to discover the attentive presence of her husband, Kumba 
invested in her apartment, making it more personal after years spent in this place that she did not really inhabit. Thus, undertaking a work of grieving enabled them to make the present exist, and to exist themselves within it.

Having finally acquired the possibility of making a link between the two faces of their history seems therefore to have involved a process of mutation, the different mainsprings of which we shall now consider. In the first instance, it was the prerequisite discovery in and through the transference of a presence unto onself and to the other, in a shared present tense, that allowed these patients to form an awareness of a link that hitherto had not been thought through between the relationship they had with their mothers and the one they had with their fathers. Indeed, a presence shared in this way engages little by little an unfurling of time, a kind of unfolding, that makes the different time periods appear as separate and differentiated, but still shot through with the same weft of desire. For the experience of "a gaze that listens" and "a listening ear that watches" seems to be fundamental for patients who have lived through such an experience of desubjectification. Indeed, through his "listening ear that watches" and that reflects the reality of a presence, the analyst seems to give body to a history, to identifications, to unconscious affects that until then had remained ungraspable. And because it "floats", his listening ear thereby acquires a density that makes a true encounter possible, giving rise to a work of elaboration. Thus, one may think that this temporal unfurling accompanies the development of the transference which, next, will be constantly revealing the way in which the unconscious defies time ${ }^{20}$, or perhaps more precisely plays with time. Indeed, clothed and endowed with a depth, the psychical time periods can then reveal their full capacity to cross over, to offer themselves up to an infinite play of the composition and recomposition of a history whose future, whose à-venir, is constantly modifying both present and past; a work of recomposition that $\mathrm{S}$. Le Poulichet has named "reversible time". ${ }^{21}$
But something else also depends on this temporal unfurling: the capacity of fright, here borne by the mother's words, to produce an effect of retroaction and thereby make new links appear, fresh significations that hitherto had gone unnoticed. Moreover, in his Les désordres du temps, Jacques André insists on the tragic dimension of retroaction, which he names through a reversal of the French signifiers: from après coup to coup d'après. And he too highlights its capacity to favorize a rewriting of the present and past tenses by underlining the role of the psychical operator of retroaction. In this way we can understand that analytic listening, by favoring an unfurling of time, has allowed for the mother's words to produce a psychical event, to lay bare the paradoxical potential of liaison, beyond the infinite violence which it once bore. Indeed, wasn't this violence necessary for the complexity of the family organization to be brought out into the open, a complexity that is founded on the lure of a submission to the father's incestual desire as a modality of access to the mother's desire, to her recognition? This speech, having been set down and then taken on board by the analytic process, far from immobilizing the psychical processes, was able on the contrary to give access to a meaning and to a history that, since the start, had been incomprehensible, and thus to participate in their "subjective becomings". ${ }^{22}$ Thereafter, time could both tie in and untie itself, instead of being mere confusion, an amalgam that could only give rise to a continuous movement of the subject's disappearence. Faced with this nondesire on the part of their mothers with respect to them, these patients could, finally, engage in a process of the reappropriation of their own desires, no longer running inexorably up against a prohibition against existing that was all the more destructive for being expressed in silence. The transference was then able to take on its full force and enable them to untangle the different fantasies by which they had been tempted, unconsciously, to give meaning to their story. So, it became possible for these 
young women not only to free themselves from two mortifying relationships but to find a new footing in the movement of life. Thereafter, conjugated in the present tense of a time that is lived and shared, both time and their bodies discovered a density and a depth of which until then they had been deprived. Indeed, over and above the new impulsion of the time periods, what was at stake was the conquest of a body that partakes of the drive, that is both desired and desiring.

\section{Conclusion}

Thus, some familial constellations can be clarified by bringing out the mother's non-desire vis-à-vis her daughter, even her desire for death. Indeed, one can sometimes observe that this is the veritable motor behind these patterns of family functioning, which alone enables the incestual bond that exists between father and daughter to be understood. For, in the fantasy of these young girls, to accept the alienation of an incestual relation should allow them, finally, to exist in the maternal gaze as subjects and as daughters.

But this is not the only effect of the mother's non-desire: often masked by the cultural forms in which it decks itself it out, it involves a misshaping of time. When considered only from the perspective of their future absence, these young women cannot gain access to the present tense of an encounter and they find themselves constantly effaced by the mother's gaze. This is when a dwarfed temporality becomes organized in which past and future, both deprived of any flesh and blood, can only become confused and deliver the subject up to ascertaining her non existence. The analytic work then favorizes the time period that allows the transference to develop: this is when a frightful word that draws back the veil on the mother's position with regard to her daughter can make way for a work of liaison that favours both the undoing of certain mortifying identifications and their fresh recomposition.

\section{Bibliography:}

André, J. (2010). Les désordres du temps. Paris: PUF. Anzieu, D. (1989). The Skin Ego (1985). (Turner, C. Transl.). New Haven, CT: Yale University Press.

Aulagnier, P. (1975). La violence de l'interprétation. Paris: PUF.

Aulagnier, P. (1991). Demande et identification. Un interprète en quête de sens. Paris: Payot.

Bick, S. (1998). Considérations ultérieures sur la fonction de la peau dans les relations d'objet précoces (1986). Les écrits de Martha Harris et d'Esther Bick. Larmor-Plage: Les éd. du Hublot.

Estellon, V. (2012). Le temps immobilisé. Cliniques méditerranéennes, 85, 131-145.

Freud, S. (1908). Creative Writers and Day Dreaming. (Grant Duff, I. F. Transl.). The Standard Edition of the Complete Psychological Works of Sigmund Freud, Vol. IX: Jensen's "Gradiva" and Other Works. London: Hogarth Press.

Freud, S. (2005). The Unconscious. (Baines, C.M. \& Strachey, J. Transl.). The Standard Edition of the Complete Psychological Works of Sigmund Freud, Vol. XIV. London: Hogarth Press (1957); reprinted in Penguin Freud Library, Vol. XI: On Metapsychology. Harmondsworth: Penguin Books Ltd (1991); (Frankland, G. Retransl.). The Unconscious. Harmondsworth Middlesex: Penguin Books Ltd.
Klopfert, D. (2010). Inceste maternel, inceste meurtrier. Paris: L'Harmattan.

Lasvergnas, I. (2008). La mère blanche. Le Coq Héron, 192, 26-34.

Le Poulichet, S. (1994). L'œuvre du temps en psychanalyse. Paris: Rivages.

Le Poulichet, S. (2003). Psychanalyse de l'informe. Paris: Flammarion.

Le Poulichet, S. (2010). Les chimères du corps, de la somatisation à la création. Paris: Flammarion.

Levi-Strauss, C. (1963). Structural Anthropology (1958). (Jacobson, C. \& Grundfest Schoepf, B. Transl.). New York: Basic Books.

Racamier, P.C. (1995). L'inceste et l'incestuel. Paris: Les éd. du Collège.

Richard, F. (2011). La rencontre clinique. Paris: Dunod. Sandor-Buthaud, M. (2009). Donner la parole à Echo. Cahiers jungiens de psychanalyse, 118, 93-100.

Winnicott, D.W. (1958). Psychoses and Child Care (1953). British Journal of Medical Psychology, 26; reprinted in Collected Papers: Through Paediatrics to Psycho-Analysis. London: Tavistock. (and again London: Hogarth Press (1975); London: Karnac Books: London (1992).

Winnicott, D.W. (1971). The Mirror Role of Mother and Family in Child Development (1967). Playing and Reality. London: Tavistock Publications. 


\section{Notes:}

${ }^{1}$ Racamier, P. C. (1995). L'inceste et l'incestuel. Paris: les éd. du collège. p. 13.

${ }^{2}$ Le Poulichet, S. (2010). Les chimères du corps, de la somatisation à la création. Paris: Flammarion.

${ }^{3}$ In this sense, we meet up with the hypothesis developed by D. Anzieu in The Skin Ego: the borderline cases, so he asserts, have been "poorly unstuck", grappling with early, chaotic relations, not having enabled the attachment drive to find adequate satisfaction.

"[Translator's note: The French "en souffrance", in its etymological definition, carries a dimension of waiting.]

${ }^{5}$ More often than not this departure refers to the coming marriage of the newly born girl; a marriage that will lead her to her "true" family: that of her father. But, as we shall see, this reference to a future absence lends itself particulary well to designating death.

${ }^{6}$ Winnicott, D. W. (1958). Psychoses and Child Care (1953). British Journal of Medical Psychology, Issue No. 26; reprinted in Collected Papers: Through Paediatrics to Psycho-Analysis. London: Tavistock, p. 219-228.

${ }^{7}$ Both of them were originally from Mali, and belonged to the Soninke people.

${ }^{8}$ With reference to "bi-dimensional" space, the shallow space that E. Bick in particular speaks about in his work on autism and adhesive identifications.

${ }^{9}$ Freud, S., (1908). Creative Writers and Day Dreaming, translated by I. F. Grant Duff in The Standard Edition of the Complete Psychological Works of Sigmund Freud, Vol. IX: Jensen's "Gradiva" and Other Works. London: Hogarth Press, p. 141-154.
${ }^{10}$ Aulagnier, P. (1991). Demande et identification. Un interprète en quête de sens. Paris: Payot.

${ }^{11}$ Lévi Strauss, C. (1963). Structural Anthropology, translated by C. Jacobson \& B. Grundfest Schoepf. New York: Basic Books:.

${ }^{12}$ Winnicott, D. W. (1971). The Mirror Role of Mother and Family in Child Development (1967). Playing and Reality. London: Tvistock Publications, p. 111-118.

${ }^{13}$ Le Poulichet, S. (2003). Psychanalyse de I'informe. Paris: Aubier.

${ }^{14}$ Ibid., p. 30.

${ }^{15}$ Ibid., p. 30.

${ }^{16}$ Ibid.

${ }^{17}$ Ibid., p. 9.

${ }^{18}$ Ibid., p. 38.

${ }^{19}$ Aulagnier, P. (1975). La violence de l'interprétation. Paris: PUF, p. 86.

${ }^{20}$ Freud, S., (1957). The Unconscious, translated by C. M. Baines \& J. Strachey in The Standard Edition of the Complete Psychological Works of Sigmund Freud, Vol. XIV. London: Hogarth Press, p. 159-215; reprinted in Penguin Freud Library, Vol. XI: On Metapsychology, Harmondsworth Middlesex: Penguin Books Ltd (1991), p. 161-222; retranslated by $G$. Frankland in The Unconscious, Harmondsworth Middlesex: Penguin Books Ltd, p. 47-85.

${ }^{21}$ Le Poulichet, S. (1994). L'œuvre du temps en psychanalyse. Paris: Rivages.

${ }^{22}$ Le Poulichet, S.. Les chimères du corps, de la somatisation à la création, Op. cit.

\section{The author:}

\section{Mireille Guittoneau, PhD}

Clinical Psychologist, holds a doctorate in Psychopathology and Psychoanalysis from the CEPP (EA 2374), Paris Diderot University at Sorbonne Paris Cité.

Campus Paris Rive Gauche

Bâtiment Olympe de Gouges

11, rue Jean Antoine de Baïf

75013 Paris

France

\section{Electronic reference:}

Mireille Guittoneau, "From the Mother's NonDesire to the "Incestual" Relationship between Father and Daughter", Research in Psychoanalysis [Online], 14|2012, published Dec. 28, 2012.

This article is a translation of Du non désir maternel aux relations incestuelles entre père et fille.

Full text

\section{Copyright}

All rights reserved 